\title{
Modern views on the structure and dynamics of biological membranes
}

\author{
A. P. Demchenko \\ Palladin Institute of Biochemistry, NAS of Ukraine \\ 9, Leontovycha Str., Kyiv, Ukraine, 01601 \\ alexdem@ukr.net
}

\begin{abstract}
Essential changes have been recently observed in views on the functioning, structural and dynamic properties of biological membranes. The previous results on hierarchical cluster-type structure of membranes and role of protein and lipid components are reconsidered. An established fact of dramatic difference in lipid composition between external and internal monolayers of plasma membranes is important for understanding membrane phenomena. In particular, there exist the differences between monolayers in surface charge and potential, ion binding, interaction with protein molecules, etc. A glycolipid component of outer monolayer and interaction of inner monolayer with cytoskeleton allow the membrane by expanding the asymmetry to attain its important functional properties. All that requires more critical approach to numerous data obtained with simplified biomembrane analogs - lipid and protein-lipid bilayer structures. In the attempts to describe and model the properties of cellular membranes there is a timely necessity to shift from two-dimensionality (which reduces the analysis to membrane plane only) to more realistic three-dimensional models.

Keywords: biological membranes, microdomains and rafts, transmembrane lipid distribution, biomembrane models.
\end{abstract}

Biological membranes are not mere barriers restricting the volume of cells and their organelles, but also participants of numerous cellular processes, including adhesion, endocytosis, immune response, generation of action potential, and apoptosis. They ensure selective exchange of substances, energy and information between the internal and external media. The functions of receptors, ion channels, transport ATPases, etc. are realized due to inhomogeneous structure of membranes, containing different proteins and lipid components. The diversity of composition and high motility of structural components do not allow determining the structure of membranes using diffraction methods. Therefore, multidisciplinary information, obtained in a wide complex of biochemical and biophysical studies, is used to understand the functions of membranes, and the analysis of these results requires the application of models which could provide simplified, but adequate idea on the mechanisms of membrane processes.

Singer-Nicolson's fluid mosaic model of membranes [1], a widely accepted foundation of the understan-

(C) Institute of Molecular Biology and Genetics, NAS of Ukraine, 2012 ding of membrane processes, was suggested 40 years ago. This paper is among the most frequently mentioned and cited works in cell biology (1,400 citations in Scopus and 4,950 - in Google Academy). There have been many suggestions on the review of this model and its possible alternative variants, which resulted in the lattice and superlattice models [2], the dynamic and structured model [3], the rafts model [4,5], the model of hierarchical organization of membranes [6]. Some authors consider Singer-Nicolson's model to be completely erroneous and unacceptable, which cannot serve as a basis for the analysis of experimental data. However, the works of many scientists show results of their experiments which are in good agreement with it. Recent literature data present many debatable articles [7-9] which require their non-judgmental analysis. This is the aim of this review.

It is extremely complicated to estimate the perspective of evolution of notions on structural and dynamic features of biomembranes in the view of results, obtained by modern methods. The modeling always implies simplification with the isolation of the most vital features of the phenomenon under study. The most significant drawback of existing models of biomem- 


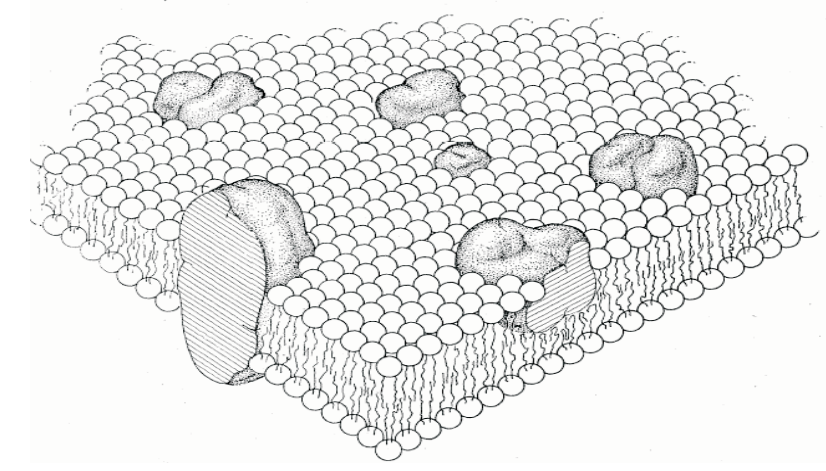

Fig. 1 The fluid mosaic model of the membrane. Integral proteins are randomly distributed in the membrane leaflet - a bilayer structure, formed by the lipid component [1]

branes is their two-dimensional nature which brings the analysis of structural and dynamic processes into the membrane leaflet only. This review concentrates on the special role of structural asymmetry of the membrane and on the presence of rapid gradients of electrostatic fields and segmental motility of components as well as on considerable difference in intermolecular interactions of external and internal monolayers of membranes.

Results of structural and dynamic modeling. A classic experiment, carried out in 1970 [10], was a vivid demonstration to the fact that membrane antigens are not distributed statically in the membrane leaflet, on the contrary, they are characterized by spatially unlimited motility. The fluid mosaic model [1] (Fig.1) was suggested as an explanation of these results, as it views the double layer of mobile lipids as a structural foundation of the membrane, and integral proteins of membranes - as mobile particles, dissolved in it, with the capacity of free and structurally unlimited diffusion in two-dimensional space of the membrane. However, some considerable inconsistencies of the model were revealed. Being similar to chaotic movement of Brownian particles, the diffusion often leads to their re-distribution between areas with high and low concentrations. Why then does the interaction of many surface receptors with hormones result in their reverse movement - the association in the membrane leaflet? This phenomenon is well-studied for tyrosinase receptors, in particular $[11,12]$. After the publication [1] the direct experimental data were obtained, contradicting the fluid mosaic model. The highest relevance was attributed to the results of Karnovsky et al. [13] who used the method of fluorescent probing to show considerable structural and dynamic hetero- geneity of phospholipids bilayer of membranes. There was an idea of phase segregation of lipids in the mem- brane leaflet with the formation of their structurally rigid clusters - rafts $[4,5,14]$. Similar phase segre- gations were also observed in model bilayer structures, created out of lipid mixtures [14]. It was established that during fragmentation of membranes in solutions of non-ionic detergents the insoluble protein-lipid complexes are preserved $[15,16]$ which led to the hypothesis on their structural correspondence to rafts.

In the meantime the optical methods of investigating intact cells were developed, the application of which allowed revealing considerable deviation of the character of dynamics from the ones, expected after the fluid mosaic model. The systemic analysis of all results allowed Damjanovich's group [3] to formulate "the dynamic and structural mosaic model" of the biomembrane. The mosaicism in it is considered as non-chaotic distribution of membrane proteins, forming small-size clusters at the molecular level and larger clusters (groups of clusters, isles) at the submicrometer level. Here the concept of "fluid nature" acquires a new meaning as the possibility for clusters to reconstruct quickly, to transform and move under the impact of external stimuli.

The abovementioned description of the fluid mosaic model implies the picture of "random drifting" of membrane proteins in the two-dimensional lipid solvent. Meanwhile, the concentration of proteins in the membrane is so high that on average only several layers of lipids may surround the protein molecule. The model of "a lipid envelope" suggests the mechanism of organization of lipid structures during the interaction with proteins [17]. Here the key organizational role is attributed to integral proteins, structuring the surrounding lipids (Fig.2).

Methods of membrane investigations, based on the concept of two-dimensionality. Biochemical methods. Isolation and characteristics of fractions, insoluble in non-ionic detergents. The disintegration of living cells and fractioning of their components always raise many questions, since the obtained supramolecular complexes may not correspond to those of the living cell. However, many researchers believe that small-size fragments of membrane 


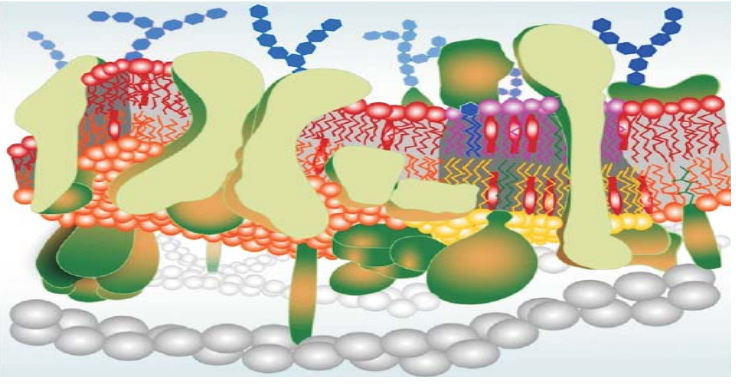

Fig. 2 One of the schemes, reflecting modern views on the membrane structure. Rather densely located integral proteins are presented next to the heterogeneous lipid component. Glycan components (above) are protruding on the cell surface, while polymer rods (below) illustrate the cytoskeleton elements, conjugated with the membrane [64]

structures, not disintegrating in solutions of non-ionic detergents, have features of rafts $[16,18]$. These membrane fractions, resistant to the detergents, actually contain increased concentrations of sphingolipids, forming rafts, and cholesterol as well as a considerable amount of integral proteins of membranes. However, the solubilizing action of such non-ionic detergents, as Triton X-100, is not restricted to the fragmentation of membranes. It may also involve the change in the content and features of membrane fragments [15]. Since the lifetime of rafts is postulated in the range of milliseconds, it is not clear how they can preserve their features during the isolation and manipulations with them.

Manipulations of cholesterol content. Cholesterol is a vital component of the raft formation; therefore, important information about the structural and functional role of the latter may be obtained, observing the effects of isolating cholesterol from the membranes of cells [19]. A simple method is the incubation of cultivated cells with methyl- $\beta$-cyclodextrin which, although does not react with the cell membrane, still "washes out" cholesterol, forming a complex with it. However, these results have to be perceived carefully, since the role of cholesterol in the membranes is not limited by the formation of structures [20].

Activity of membranotropic factors. Many substances of natural and synthetic origin are capable of getting involved into biomembranes and modifying their features. Noteworthy is the activity of long-chain polyunsaturated fatty acids (Omega 3 type), increasing the formation of clusters in cholesterol-dependent microdomains of membranes [21].
Introduction of various markers and probes. At present a wide-spread method is the introduction of fluorescent markers and probes into the membranes [22-24]. In particular, this is covalent staining of the domains of integral proteins, exposed on the cell surface, and the introduction of stained lipids or fluorescent probes with amphiphilic features, similar to lipids, into the membrane. Testing of these stained lipids on model phospholipid vesicles is essential, since the binding of a fluorescent group to lipids often changes the specifics of building into $\mathrm{L}_{0}-$ or $\mathrm{L}_{\mathrm{b}}$-phase of the membranes [23]. A series of fluorescent analogues of cholesterol were elaborated [24]. The application of molecular design allows not only studying the distribution of fluorescent molecules in the membranes, but also placing the fluorescent group into the membrane at the certain depth and in required orientation [25].

Wide application is remarkable for fluorescent stained recombinant fragments of antibodies. The combina tion of staining methods with the registration of resonance energy transfer enables the determination of mutual localization of different protein and lipid com- ponents, and the identification of rafts, in particular [26].

Biophysical methods. The principle of two-dimensional contrast is often used in the study of cell membranes [27]. The methods of fluorescence are the most popular optical methods, enabling high sensitivity while obtaining the images using modern methods of microscopy - confocal, two-photon, and evanescent-wave. Still the separating power of the mentioned methods is limited by the phenomenon of light diffraction and cannot exceed $\approx 200 \mathrm{~nm}$, and the sizes of the focal plane cannot be below $500 \mathrm{~nm}$. The application of new optical principles and the progress in the elaboration of devices allow evading this restriction [28-30], but it is not real to achieve the level of separation, which would exceed the width of the membrane of 3-5 $\mathrm{nm}$.

The study of biomembranes stimulated the development of more specific approaches, which can conditionally be divided into methods, ensuring statistically averaged information on the motion of stained nanoobjects (FRAP), allowing the analysis of their specific motions (SDT and SPT) as well as their interaction at distance (FRET) [27, 31]. 
Fluorescence Recovery After Photobleaching (FRAP). This method allows determining the rate of diffusion for fluorescently stained molecules in the membrane leaflet [27]. Intensive laser beam is focused on a small area of the membrane surface; it causes bleaching (irreversible photochemical inactivation) of lighted marks. Then the probing beam of low intensity enlightens the same volume and the fluorescence intensity increases due to the diffusive penetration of labeled molecules therein. The analysis of this kinetics allows determining the coefficient of translational diffusion of labeled molecules or particles.

Decades-long application of this approach revealed its significant drawbacks. The membrane should be immovable while the process of filling the investigated volume should be diffusive, then the result will not depend on the size of the lighted volume. The determination of such dependence [27] indicates the fact that the dynamics of mosaic structures in membranes is not governed by the law of simple diffusion.

Single Dye Tracking (SDT); Single Particle Tracking (SPT). The application of these methods ensures the direct observation of diffusion of molecules and particles and is the alternative to FRAP [27]. Contrary to the latter, the fluorescence signal is not averaged according to the ensemble of emissive molecules, but their single motion is detected. SPT uses antibodies against the membrane protein, loaded with fluorescent nanoparticles or particles of colloid gold, scattering the light. The series of pictures, obtained in temporal dimension, are used to calculate the motion trajectory and diffusion coefficient. However, a considerable size of nanoparticles is a significant drawback. The development of experimental equipment allows tracking the motion of single molecules [32] including organic dyes and analogues of green fluorescent protein.

Fluorescence Correlation Spectroscopy (FCS). The illumination of a very small volume $(\approx 1 \mathrm{fl})$ allows recording fluctuation of photons, occurring when separate molecules enter and leave it [33]. Temporal observation of this motion enables obtaining the autocorrelation function which allows estimating the diffusion coefficient. The sensitivity of this method is low in detecting slow motion of large protein molecules, but it allows obtaining important information on the character of diffusion processes due to the variations of the sizes of the lighted volume [27, 33, 34].

Forster Resonance Energy Transfer (FRET). This method is not related to a certain volume and is sensitive to the interaction between separate molecules [35]. If two labeled molecules are close (in the range of $\approx 0.5-1 \mathrm{~nm}$ ), during the optical excitation of one molecule (donor) the excitation energy may be transferred to another molecule (acceptor) that results in change of color and polarization of fluorescence. Therefore, there is a possibility of estimating the distance between the donor and the acceptor. The acceptor does not always emit fluorescence, in this case FRET is registered as a decline in the lifetime of donor fluorescence $[36,37]$. FRET with labeling of membrane components is widely used in the fluorescent microscopy of cells [38].

It should be noted that the limiting resolving power of the described methods, using fluorescent microscopy $(200-500 \mathrm{~nm})$, is two orders lower than the width of membranes, therefore, through the prism of these methods the latter look like two-dimensional structures. The same is true for FRET [39]. The distance between the donor and the acceptor may be smaller than $1 \mathrm{~nm}$, but the location of this couple cannot be determined with such precision.

Physical modeling of interactions in membranes. The physical theory has no explanation for the coexistence of dynamic nanosize phases at equilibrium. The interaction of $\mathrm{L}_{0}-\mathrm{L}_{\mathrm{d}}$-phases in model membranes results in phase separation with the formation of clusters of significant size [40]. Why then does not that occur in the membranes of living cells? The domains with the size under $200 \mathrm{~nm}$ are of great interphase surface energy. There are many explanations of this fact and none of them is satisfactory [41]. The problem is that the lateral interactions of lipids are rather weak to keep this separation of phases. Their stabilization by proteins cannot be efficient due to mobile lipid surrounding. The dynamics of clusters is the most obscure, including their association during the stimulation of receptor proteins. This led to the presently unconfirmed hypothesis on continuous internalization of large rafts by cellular mechanisms and their substitution by smaller ones [42].

Taking into account the impossibility of obtaining structural and dynamic information with all the 
molecular details in a modern experiment, researchers place their expectations on the development of computer methods of investigating molecular dynamics. Considerable complexity of membrane systems requires infeasible large volumes of calculations; therefore, simplified "coarse-grained" models are suggested and developed [43].

Investigations of membrane structures of different complexity. Phospholipid bilayer structures. Phospholipid bilayer structures are used as the material for membrane construction, thus, the research was aimed at the investigation of flat supported bilayers as well as large membrane vesicles [40]. These structures enable wide variations of the lipid composition and observing changes in the physical features of membranes. At low temperatures the phospholipids form a solid or gel $\left(\mathrm{S}_{0}\right)$ phase, at increased temperature there is a transition to the "fluid" disordered phase $\left(\mathrm{L}_{\mathrm{d}}\right)$ with irregular location and fast dynamics of acyl chains segments. However, the presence of sufficient amount of cholesterol may allow the formation of so called "fluid ordered" $\left(\mathrm{L}_{0}\right)$ phase that is characterized by high chains order (similar to $\mathrm{S}_{0}$-phase), but also by high translational motility of molecules (almost similar to $\mathrm{L}_{\mathrm{d}}$-phase). Since $\mathrm{L}_{0^{-}}$and $\mathrm{L}_{\mathrm{d}}$-phases may coexist, forming isles of one phase in the other, there was an assumption regarding structural correspondence of $\mathrm{L}_{0}$-phase to those regular microdomains present in natural membranes, which are called "rafts" [14]. However, there are sufficient reasons to criticize this assumption; in particular, it is difficult to compare the phase transformations of three lipid components with the situation in natural membranes, containing hundreds of components. The more components, the less expressed the phase transitions should be. An essential argument should also be the fact that L0-phase areas in lipid bilayers are of considerable size, while the rafts in natural membranes do not amount to hundreds of nanometers. Here the diffusion of lipids also occurs 5-100 times faster than in natural membranes [40].

Besides rafts, the interest of researchers is greatly attracted to the existence of so called ceramide microdomains [44], formed due to the association of cholesterol with ceramides - products of enzymatic splitting of sphyngomyelin (SM). It is believed that these structures have signalling features, are localized in cells and created by sphyngomyelinase.

Protein-membrane complexes. After the preliminary isolation and purification the membrane proteins may be incorporated into phospholipid bilayers. They create a shell of the most affine lipids around themselves, and also are capable of changing the character of phases $\mathrm{L}_{0} / \mathrm{L}_{\mathrm{d}}$. As shown for N-ras protein [45], proteins may be localized in the interphase between $\mathrm{L}_{0}$ and $\mathrm{L}_{\mathrm{d}}$, thus decreasing the effects of superficial tension between them. Peptides and proteins are capable of inducing the formation of rafts in these systems [46]. However, there is experimental evidence to the fact that in phospholipid membranes the proteins, isolated from rafts, are incorporated into irregular Ld phase rather than in $\mathrm{L}_{0}$ phase [47]. Thus, the analysis of results of such investigations should be carried out with caution.

Vesicles of natural components of biomembranes. Since phospholipid bilayers and manipulations with them due to the incorporation of new lipid and protein components are considerably simplified, currently vesicles are formed of natural cell membranes. These investigations are carried out with reservations relative to the fact that rather strict methods of obtaining these objects, for instance, the application of formaldehyde, can affect their composition and features [48]. It was demonstrated that the separation of phases can be observed in the obtained vesicles and in the simulated phospholipid bilayer structures [49]. Creating certain phase conditions, these areas of the structure are capable of specific binding of certain proteins. The observations of the temperature dependence of specific features of these structures gave grounds for the idea on the existence at physiological conditions of a critical area for coexistence of separate phases [50].

Membranes in the investigation of living cells. FRAP and FCS methods in experiments on cells allowed revealing a considerable difference of the translational movement of labeled membrane proteins from free diffusion [3] which indicates considerable hindrances. However, since these methods have smaller spatial resolving power than the size of microdomains, it is not possible to determine the molecular organization of the latter. In particular, it is not possible to answer the question of what kind of 
lipid surrounding the integral protein has and in what way this complex is incorporated into the raft [51]. Meanwhile, these results bring evidence to the hierarchical organization of microdomains and the dynamic character of their formation and breakage [6] as well as to the presence of several types of microdomains with different incorporation of fluorescent analogues of lipids.

Different cells respond to external perturbation by segregation of their receptors, i.e. their capping in one area of the membrane. For instance, it occurs during the binding of polyvalent antibodies, investigated on lymphocytes [52] and during the interaction of membrane gangliosides and ligands [53]. Membrane receptors are structuring creating concentration gradients during their motion. This process cannot be understood using two-dimensionality of the membrane.

Thus, the results of recent experiments move us further away from the sometime revolutionary fluid mosaic model of Singer-Nicolson. One cannot assert that it is completely wrong, as it postulates high level of molecular dynamics in the membranes, proven by the experiment. However, this dynamics is considerably different from Brownian diffusion. The mosaicism of the structure and the hierarchical character of this mosaic prove to be the most important membrane features.

Current models deal with two-dimensional coordinates in the membrane leaflet. Meantime, the biophysical methods of investigation, most frequently used to study both living cells and different membrane models, provide essentially two-dimensional information (translational movement of membrane components and their interaction in the membrane leaflet) [27]. Therefore, the most urgent question is as follows: can functionally significant processes in the membrane be modeled by structural and dynamic changes in its leaflet only? If the answer is positive, the results mentioned in the sections above, obtained on phospholipid models and isolated membranes, are of great value. If the answer is negative, their value is minimal and it is essential to concentrate on the development of adequate approaches to the investigation of living cells.

Three-dimensionality of the membrane as structural foundation of its existence. The main events in the cellular membrane occur in the direction, perpendicular to its leaflet rather than in the leaflet proper. This is the signalling activity, and the exchange of metabolism products, and the creation of ion gradients. Different classes of proteins, surrounded by lipids, are asymmetrically located in the membrane. The photosynthesis in chloroplasts and the energetic processes in mitochondria are related to transmembrane processes. All these processes are vectorial and highly selective; therefore, it would be considerably simplified to consider membranes as two-dimensional partitions. The most vivid confirmation of the necessity of the analysis of membrane three-dimensionality is different lipid composition of monolayers in the bilayer structure, their different surface potential, differences in the ion binding affinities and in the energy of interaction with macromolecules and supramolecular structures.

Methods of investigating the structural asymmetry of biomembranes. Due to the asymmetry in the distribution of lipids among monolayers, the two surfaces of the membrane differ in their biochemical features and in the implementation of their functions. Let us review the methods of investigating the lipid composition of monolayers and the results obtained.

The isolation of membrane fractions along with the proteins, localized on either external or internal monolayers. This method proved that different non-ionic detergents solubilize membranes with the isolation of rafts in a different way [54]. It is in good agreement with the localization of phosphatidylethanolami ne $(\mathrm{PE})$ in the internal monolayer of plasma membranes.

Chemical modification and labeling. The labeling of lipids, containing free amino groups, $\mathrm{PE}$, and phosphatidylserine (PS), on the surface of cells using reagents, not penetrating the internal monolayer, occurs in a simple and efficient way $[55,56]$. The most popular reagent is 3-nitrobenzenesulfonate (TNBS). The application of electron paramagnetic resonance (EPR) or fluorescence requires corresponding labeling. As for EPR, these are doxyl derivatives. If they get to the surface of the membrane, their restoration by the ascorbate is possible [56]. 7-nitrobenz-2-oxa-1-?-3-di azol-4-yl (NBD) dye is most frequently used for fluorescent labeling. If NBD group is exposed on the surface, it can be restored using dithionite with the loss of fluorescence [57]. At present there are many synthesized labeled lipids which are capable of 
spontaneous incorporation into the membrane and mixing with natural lipids, but there is no guarantee that their properties will correspond to the features of natural lipids. The application of NBD-derivatives of cholesterol has been described [58]. The application of so called biorthogonal labeling of lipids, ensuring high selectivity, is very promising for membrane investigations [59].

The application of lipid-binding proteins foresees the involvement of anti-lipid antibodies and their recombinant fragments as well as proteins, specifically interacting with lipids. The use of annexin $\mathrm{V}$, which has very high affinity to PS by coordination with it via calcium ions, proved to be the most widespread. Many variants of this method were elaborated, when annexin $\mathrm{V}$ is modified by isotope or fluorescent staining [60]. The antibodies against phospholipids and even against cholesterol are used [61].

Degradation by phospholipases of different specificity. The method is used to determine superficial localization of the lipid, but it requires long-term incubation, besides, the products formed (lyzo derivatives and fatty acids) can destabilize the membrane [62].

All these methods have drawbacks, but their systemic use allows revealing the picture of the complex structure of the membranes.

Transmembrane distribution of phospholipids. It was determined for many types of the membranes that the lipid composition of the external membrane monolayer has considerable differences from this internal monolayer $[63,64]$. This difference is variable depending on the type of the cell or organelle, to which the membrane belongs. For instance, it was not observed in the membranes of endoplasmic reticulum. At the same time it is expressed most vividly in Golgi apparatus, in endosomes, and in plasma membranes of eukaryotes, which is illustrated in Fig.3 of ref. [64]. SM and glycosphingolipids are mostly located on the external side of plasma membranes, while anionic PS and phosphatidylinotol (PI) and its phosphorylated forms as well as PE are concentrated in the cytosol monolayer. SM, forming rafts, is mainly located in the external monolayer; its association with cholesterol allows observing the segregation of $\mathrm{L}_{0}$-phase in model membranes, which is the basis of raft formation [65]. This $\mathrm{L}_{0}$-phase cannot be formed out of anionic phospholipids in the combination with PE in model bilayers [66]. The location of cholesterol is vital. Since the cholesterol content often correlates with the content of sphingolipids, it is reasonable to assume that cholesterol is mainly localized in the external monolayer, where rafts are formed. However, there is no clear experimental confirmation yet. It is noteworthy that in simulated membranes cholesterol prefers lipids with the polysaturated structure of carbohydrate "tails", it does not create rafts, if double bonds are there [67].

Inositol phospholipids are known for their phosphorylated forms [68], playing an important role in regulatory mechanisms of the cell. They are localized in the internal monolayer of cytoplasmic membranes and participate in transferring signals between the membrane and the cytoplasm as well as in the interaction of the membrane and the cytoskeleton.

The asymmetrical distribution of neutral and anion lipids in membranes plays a vital yet not completely investigated functional role. It is known about its essential relevance for intercellular interactions, activation of the cascade of blood coagulation, recognition and elimination of apoptotic cells. The signal, launching these processes of cell recognition, is the occurrence of PS and PE in the superficial monolayer [69].

Transmembrane distribution of cholesterol. The stoichiometric complexes of cholesterol and lipids demonstrate high stability so that excessive cholesterol is easily washed out of the membrane. In the cytoplasm it becomes the substrate of cholesterol oxidase, and in extracellular space it is bound with lipoproteins of high density [70, 71]. It allows regulating the cholesterol content in the membrane regarding the quantity of phospholipids, affinity to it, and ensuring its corresponding (asymmetrical?) correlation between the external and internal monolayers of the plasma membrane. Its equilibrium distribution between monolayers was studied using different approaches, in particular, the method of fluorescence quenching of fluorescent dehydroergosterol, or of fluorescent derivatives of cholesterol, labeled at OH-group by the quenchers introduced from outside [24]. However, there have been no unequivocal results obtained [71], and several researchers believe that the majority of cholesterol molecules are located in the internal 


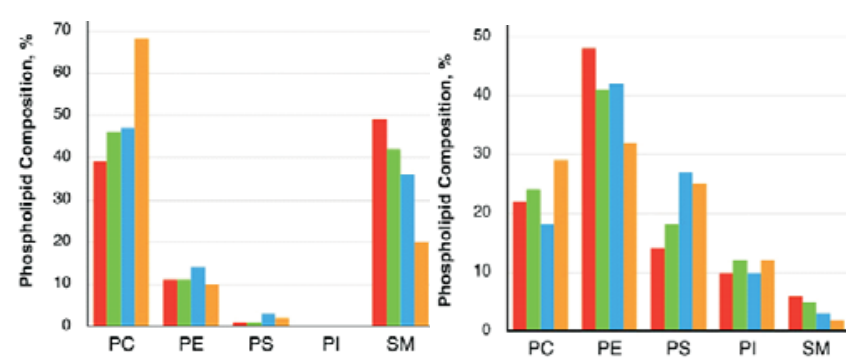

Fig. 3 The distribution of lipid components of membranes between the external (to the left) and internal (to the right) monolayers of plasma membranes. The results for phosphatidylcholine (PC), phosphatidylethanolamine (PE), phosphatidylserine (PS), phosphatidylinositol (PI) and sphingomyelin (SM). The columns illustrate relative concentration of lipids (from left to right) in the membranes of human erythrocytes, blood platelets, lymphoid cancer cells and mucosal mast (RBL-2H3) cells [64]

monolayer. Since it has high affinity to lipids with polysaturated chains, phospholipids are distributed by this feature as well. Cholesterol reveals considerable affinity to some integral proteins which can also influence its distribution [72] and stabilize protein-lipid domains, rich in cholesterol.

Transmembrane dynamics of lipids. Contrary to almost non-barrier translational movement of lipids along the membrane leaflet, the flip-flop of lipid molecules from one monolayer to the other requires the transfer of the polar head of the lipid via the hydrophobic part of the membrane. Its spontaneous occurrence is extremely slow (rate $\sim 10-15 \mathrm{~s}^{-4}$ ), therefore, the equilibrium condition is achieved in hours or even days [73]. This process is considerably faster in the living cells. There are a number of enzymes, which create and support the structural asymmetry of membranes (flippases and floppases) $[74,75]$. Transferring lipids, they use the energy of ATP for the creation of non-equivalent distribution of the latter. There are other translocases - scrambases, carrying out the transfer of lipids that is coupled with transfer of calcium ions. These processes allow achieving controlled dynamic equilibrium in the distribution of lipids in several minutes. In some functional conditions (the activation of blood platelets) the asymmetry of plasma membranes is violated; anionic lipids appear at the outer monolayer [69].

Therefore, the differences in the physical properties of external and internal monolayers of the membranes (in particular, their surface electrostatic potentials [76]) are ensured by the dynamic maintenance of stable concentration gradients.

There is no high energetic barrier for the flip-flop of ceramides (derivatives of sphingolipids without polar heads), that is why their redistribution is extremely fast (takes seconds) $[77,78]$. It is known that ceramides can accelerate the flip-flop of other lipids.

The transmembrane flip-flop of lipids is a very important mechanism in the biogenesis of membranes. The transfer of glycolipids, polar glycan components of which should be exposed on the external monolayer, is especially complicated [79].

Correlation between the structural organization and dynamics of monolayers. Thus, the dramatic difference in the lipid content between monolayers of the same membranes is an undisputable fact. This implies some differences in such properties as surface electrostatic potential, hydration, capability to interact with molecules and ions on the surface. Meanwhile, the signaling functioning of the membrane requires synergism of interactions between monolayers. This function of transmitting a signal may be performed by integral proteins. However, the role of minor lipids as primary and secondary signal transmitters through the membrane is also known. So how independent are the lipid monolayers and how is their interaction implemented?

If rafts exist in both monolayers, and sphingomyelin - the most powerful creator of rafts - is localized only in the external monolayer, it is not clear what lipids and in what combination play this role in the internal monolayer? In many works the rafts are presented as symmetrical in both monolayers. Is it true? (See Fig. 4). So, can rafts, formed in the external monolayer, induce their formation in the internal monolayer? This would contradict the known data about the interaction of monolayers with hydrophobic ends of acyl chains only, and the weakness of these interactions. However, it is noteworthy that in model membranes, where the separation of $\mathrm{L}_{0}$ - and $\mathrm{L}_{b}$-phases can be observed, the clusters of these phases in both monolayers coincide [80]. There were attempts of creating artificial asymmetrical bilayers, composed of lipids only. The simultaneous formation of the rafts in both monolayers indicates their possible formation without the participation of integral proteins [81]. 

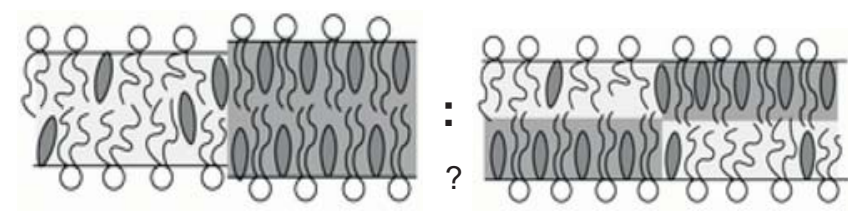

Fig.4 The illustration of problems, occurring in the framework of the model of rafts. Do the rafts (shown as darkened structures), formed in the same monolayer, correlate and interact with the rafts from another monolayer? Does the reconstruction of the rafts occur with the establishment of such interaction under the application of external stimuli?

These results require some explanations. One of them is the correlation of dynamics of acyl ends, which can intertwine inside the bilayer [82]. If this is true, the role of cholesterol is not clear. On the one hand, it makes the intertwining (interdigitation) of acyl chains in $\mathrm{L}_{0}$-phase impossible and does not prevent it in $\mathrm{L}_{\mathrm{b}}$-phase. On the other hand, it migrates easily among monolayers into the areas where its thermodynamics stability is the highest.

Searching for the answer to the question on the mechanisms of signal transmittance between monolayers, there have been many experiments in binding the cationic peptide poly-L-lysine. Without the participation of rafts-forming lipids, this binding is sensed at the opposite side of the membrane. Moreover, these peptide molecules when applied on both sides of the membrane migrate in the membrane leaflet like one single unit [83]. The correlation in the dynamics between the external and internal monolayers is implied by the investigation of T-lymphocytes with the fluorescent protein, incorporated into the internal monolayer of their membranes [84]. These results contradict other data [85] where the correlation of microdomains of the internal monolayer was revealed not with the domains of the external monolayer, but with the interaction with the actin cytoskeleton.

Thus, at present it is not clear whether the asymmetry in the composition of phospholipids can hamper the correlated formation of symmetrical physical state of monolayers in the bilayer structure. If this is true, there should be some clear-cut mechanisms of this correlation. It can have an important functional role, for instance, for vectorial incorporation into the membrane of integral proteins.
Glycolipids, exposed on the cell surfaces. The additional factor, distinguishing the external surface of many cellular membranes, is the presence of carbohydrate components (glycans), integrated with lipids. First of all, these are glycosphingolipids with hydrophobic ceramide part, integrated into the membrane, and the oligosaccharide chain, protruding into the extracellular space. These completely hydrated chains may take a considerable part of the cell surface. They are easily associated with SM and cholesterol and considered to be characteristic markers of rafts. Their especially high concentration (up to $10-12 \%$ of all the lipids) is in the neuronal membranes. Their presence in large amounts in one monolayer only raises many questions regarding the structural and dynamic organization of the membranes [86, 87].

Glycosphingolipids GM1 and GM3 are used as markers of rafts; their segregation on the surface of cells (which can be observed due to the effect of binding the fluorescently labeled subunit B of cholera toxin) testifies to high motility of these structures [85].

The relevance of investigating glycosphingolipids is related to significant role attributed to them not only as antigens and factors of intercellular interactions, but also as active participants of signalling processes, requiring transmembrane integrated response [88].

Interaction of cell membrane with the cytoskeleton and other factors of the cytoplasm. It is known that integral proteins of membranes are capable of moving against the concentration gradient in the two-dimensional space of the membrane, grouping into clusters [89]. It testifies to the presence of the correlation in their movement and to the presence of the driving force outside the double layer. The interaction with the cytoskeleton can bid for the role of this force, but little is known about the way this interaction is implemented [90, 91]. The investigations of the interaction of rafts and the actin cytoskeleton during the activation of T-lymphocytes suggest the control by the cytoskeleton, and, particularly, by the actin filaments of the perimembrane space of the cytoplasm, over the creation and segregation of microdomains [85, 92, 93]. However, the details of this interaction mechanism are still not clear. The only definitely established fact is reasonably considered to be the interaction of anionic lipids, PS, in particular, with 
actin fibrils on the internal surface of the membrane [94].

The model of erythrocyte membranes was used to demonstrate that the exposure of PS on the surface weakens the bond of the membrane to the spectrin-actin system and affects the mechanical properties of the cells [95]. The actin cytoskeleton of cells is a dynamic structure, modulating the transfer of integral proteins onto membrane surface. However, its effect may spread to the structuring of lipids of the internal monolayer.

Integral properties of biomembranes. The organization of protein and lipid components into a complicated aperiodic supramolecular structure, which is the biological membrane, leads to the occurrence of new integral properties, the electrostatic potential of the membrane, first and foremost [76]. The detailed analysis of its non-monotonous change in the crossection of the membrane allows distinguishing its components, including transmembrane, dipole and surface potentials [76]. Enormous gradients (i.e. changes in short distances, amounting to mere fractions of nanometer) are observed for other parameters of the membrane, such as polarity, hydration and viscosity [96].

Asymmetry of superficial charges and electrostatic potentials. The occurrence and maintenance of the membrane potential is an actual problem in cell physiology. Macroscopic models provide rather satisfactory description of this process, but it is not completely clear at the molecular level in the terms of dynamics of interactions between ions, water and lipids. The ion adsorption of the surface of the membranes and their distribution in the perimembrane depend on the phospholipid composition, and since this composition differs for various monolayers, the distribution should also be different (Fig.5). Special relevance for this distribution is attributed to the differences in ion concentrations in the external and internal volumes, separated by the membrane (in particular, relatively high concentrations of $\mathrm{K}^{+}$in the cytoplasm and $\mathrm{Na}^{+}$in the external volume of cells) [97].

Estimates using molecular dynamics (MD) methods. The investigations using MD methods demonstrated that while binding at the level of the lipid carbonyl groups, $\mathrm{Na}^{+}$, show higher affinity to the membrane than $\mathrm{K}^{+}$, but the higher concentration of the latter results in its more efficient binding in the internal monolayer. The negative charge of the surface, created by the heads of anionic lipids, plays an important role in the binding [98]. Along with the charges of lipid heads, the bound ions determine the value of transmembrane potential [99]. Unexpectedly, MD simulation on a simple model (homogenous phospholipid membrane of PS with equal concentrations of $\mathrm{NaCl}$ and $\mathrm{KCl}$ ) demonstrated a considerable difference of potentials $(-70 \mathrm{mV})[100]$ instead of zero potential due to stronger binding of $\mathrm{Na}^{+}$but not $\mathrm{K}^{+}$ions at the level of lipid carbonyls. As for anions, their interaction with the membrane is different. For instance, chlorides create only the effect of a counter-ion to the cation, bound to the membrane [101].

Application of fluorescent probes. The non-invasive obtaining of results about electrostatic interactions at the level of groups of atoms requires the instruments of molecular and submolecular size, the high sensitivity of response of which would provide for their non-invasive application. These instruments are fluorescent labels and probes [76, 96, 102]. Considerable advantages of these molecules is their suitability for microscopic investigations and for the obtaining of multiparametric response from them [103]. This may include the response to intermolecular interactions (electrostatic potentials and the effects of hydration and polarity by the spectral shift of excitation and emission spectra, the occurrence of new bands in spectra), microviscosity (the dynamics of the rotating movement detected by the emission anisotropy) and the spatial vicinity between the labeled molecules (FRET by time-resolved fluorescence). The possibility of using fluorescent molecules, which are binding only in one monolayer at different penetration level or orientation in the membrane, is important [104].

Among the recent achievements the method of recording the optical second-harmonic is especially remarkable since it improves the photoselecting capacity at anisotropic interphase considerably [105] and allows visualization of cholesterol-rich domains [106]. Fluorescent analogues of lipids were created for the application in two-photon spectroscopy and microscopy $[107,108]$. There was successful synthesis of fluorescent molecules, not penetrating the cell, with the response to its surface potential [109], which were used to obtain the response to the exposure of anionic 


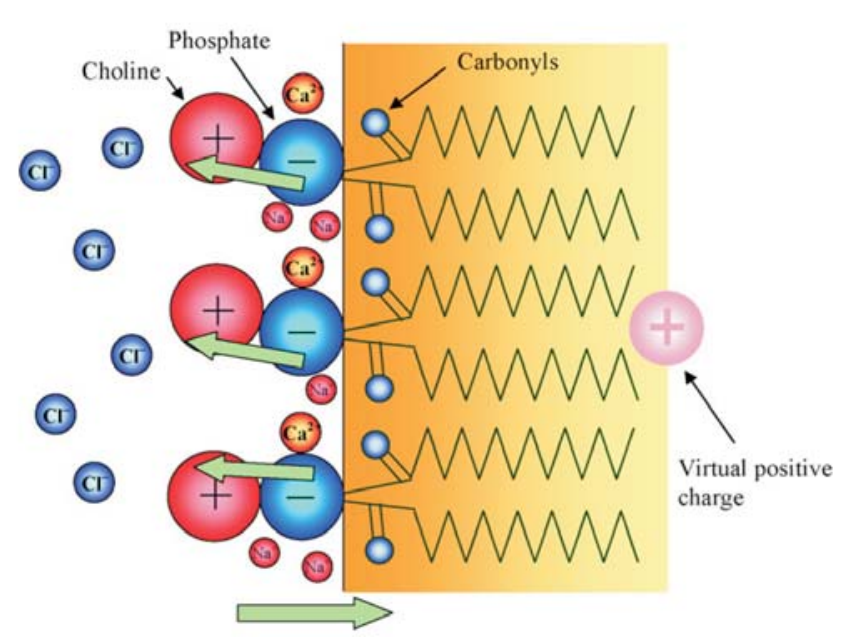

Fig.5 The schematic presentation of electrostatic interactions in structures, formed by ordered phospholipids. Cations $\mathrm{Na}^{+}$and $\mathrm{Ca}^{2+}$ interact with lipid heads at the level of phosphate groups, while anions $\mathrm{Cl}^{2}$ form mobile atmosphere near the membrane. Together with the water dipoles (not shown) the dipoles of heads and carbonyl groups generate dipole potential, which is expressed by the occurrence of a virtual charge in the center of the bilayer [76].

lipids to the surface at early stages of apoptosis. Electrostatic interactions of cationic lipids and positively charged protein domains with negatively charged surface of the membrane determine their integration into the membrane and transfer through it $[97,110]$. It is believed that this mechanism is active in endosomes and lisosomes, while the ejection of calcium ions restrains these effects.

Transmembrane signal transmission occurs not only according to the mechanism of transfer of molecular messengers but also due to the induction and distribution of changes in membrane structures. The mechanisms of such signal transmission have not been clearly established, and they may be different. Firstly, this is allostery, i.e. correlated conformational changes of the integral protein which transpierces the membrane completely [111]. Secondly, this is the induction of changes in the correlated dynamics of lipids, belonging to adjacent microdomains of monolayers. Thirdly, this is lateral diffusion of protein receptors, which may lead to raft clusterization; this diffusion ensures the correlation between binding of a polyvalent ligand on the surface and intracellular changes. The latter may be implemented via the system of G-proteins or using tyrosine kinase receptors. The reorganization of the actin cytoskeleton is also possible.
Further progress in this field requires the choice of adequate models. One of them can be found in immunological synaps - a dynamic structure, formed between a T-lymphocyte and the cell, carrying a surface antigen $[112,113]$. During its formation there is segregation of proteins and lipids in contacting membranes which creates conditions for multi-channel transfer of the information, necessary for the cell to choose between the activation and tolerance. If the segregation of rafts by the membrane creates a transmembrane signal, what is the mechanism of generating this signal?

Perspectives: from simulative two-dimensionality to real three-dimensionality. It is difficult to coordinate the historically relevant and interesting model of Singer-Nicolson with modern experimental data. Postulating high motility of both lipids and proteins in the membrane leaflet, it played a very important role. According to this model, a membrane is a two-dimensional viscous solution of lipids where integral proteins diffuse. At present we realize that a lipid component can hardly be called a homologous two-dimensional solution. It forms microdomains of subnanometer size (rafts) with hierarchical organization and complex dynamics. The movement of proteins is far from being a free diffusion; rather, it consists of jumps via potential barriers in microdomain space, accompanied by the reorganization of these microdomains. But the most important fact is that even at first approach the membrane cannot be considered a two-dimensional structure, as the concentration equilibrium of lipids along Z-direction (normal to the membrane) is absent. This non-equilibrium condition is actively supported by energetically dependent processes, due to which the equivalence of monolayers in binding ions and small molecules is absent. The monolayers are hydrated in a different way and have unequal charge and surface potential, while the properties of the internal monolayer are considerably determined by the interaction with cytoskeleton proteins. The participation of the cytoskeleton ensures the spatial correlation of motions of membrane proteins. It is impossible to perceive the mechanisms of many membrane processes without taking these relevant properties into account.

A biological membrane is a fantastically interesting object of molecular and cellular investigations. This 
structure, only $4-5 \mathrm{~nm}$ wide, is not only the verge between life and death for the cell. Its capability of selective exchange of numerous substances and multiplane information, its extremely complicated organization and constant self-reproduction require the researcher's spatial and temporal simulation with mandatory introduction of $\mathrm{Z}$ coordinate. At present there is an evident imperfection of models and concepts, based on the experimental material. Many issues are controversial. If there can be an artificial membrane, composed of 1- 2 components only, why then does the cell synthesize hundreds of various lipids, spending about $5 \%$ of its genes [114]? If the same or similar structural and dynamic organization of microdomains can be realized in both monolayers, why then is considerable energetic resource of the cell involved into the constant maintenance of transmembrane asymmetry of lipids?

And finally, what is a biological membrane? First of all, this is an anisotropic structure in all the three dimensions. This is a non-equilibrium structure, where concentration gradients are created and constantly supported. Due to this fact and to the integration of different proteins and non-protein components, the monolayers of this bilayer structure are drastically different in their composition, electrostatic potential of the surface formed, and the binding of ions. A plasma membrane interacts with the cytoskeleton. Besides transmembrane transfer of molecules, the transmission of functionally relevant signals occurs due to the correlated structural changes in the membrane. All these properties cannot be reproduced in any of simplified model systems.

At present the synthetic biology, the main task of which is the artificial formation of a minimal cell, paves its way. The implementation of this task is hardly possible without clear understanding and practical reproduction of the main functions of biomembranes.

\section{О. П. Демченко}

Сучасні уявлення про структуру і динаміку

біологічних мембран

Інститут біохімії ім. О. В. Палладіна НАН України

Вул. Леонтовича, 9, Київ, Україна, 01601

Резюме
Останнім часом відбулися істотні зміни у поглядах на функиіонування і структурно-динамічні властивості біологічних мембран. Переглянуто дані щодо ієрархічної кластерної будови мембран $i$ ролі білкових і ліпідних компонентів. Встановлено факт драматичної різниці ліпідного складу між зовнішнім і внутрішнім моношарами плазматичних мембран, який має важливе значення для розуміння мембранних прочесів. Зокрема, існують відмінності між моношарами у поверхневому заряді і потенціалі, зв 'язуван-ні іонів, взаємодії з молекулами білків тощо. Гліколіпідний компонент зовнішнього моношару $i$ взаємодія з иитоскелетом внутрішнього моношару дозволяють мембрані через поглиблення асиметрії набути важ- ливих функиіональних властивостей. Необхідний більи критичний підхід до результатів, одержаних зі спрощеними аналогами біомембран - ліпідними і білково-ліпідними бімаровими структурами. У спробах описання і моделювання властивостей клітинних мембран існує потреба відходу від двовимірності (що зводить аналіз лише в площину мембрани) і переходу до більш реалістичних тривимірних моделей.

Ключові слова: біологічні мембрани, мікродомени і рафти, трансмембранний розподіл ліпидів, моделі біомембран.

\section{А. П. Демченко}

Современные представления о структуре и динамике биологических мембран

Резюме

В последнее время произошли существенные изменения во взглядах на функиионирование и структурно-динамические свойства биологических мембран. Пересмотрены данные о иерархичном кластерном строении мембран и роли белковых и липидных компонентов. Установлен факт драматических различий липидного состава между наружным и внутренним монослоями плазматических мембран, имеющий большое значение для понимания мембранных прочессов. В частности, существуют различия между монослоями в поверхностном заряде и потенциале, связывании ионов, взаимодействии с белковыми молекулами и т. д. Гликолипидный компонент внешнего монослоя и взаимодействие с ицтоскелетом во внутреннем монослое позволяют мембране за счет углубления асимметрии приобрести важные функииональные свойства. Необходим более критичный подход к многочисленным результатам, полученным с упроченными аналогами биомембран - липидными и белково-липидными бислойными структурами. В попытках описания и моделирования свойств клеточных мембран существует актуальная потребность отхода от двухмерности (что сводит анализ лишь в плоскость мембраны) $u$ перехода к более реалистичным трехмерным моделям.

Ключевые слова: биологические мембраны, микродомены и рафты, трансмембранное распределение липидов, модели биомембран.

\section{REFERENCES}

1. Singer S. J., Nicolson G. L. The fluid mosaic model of the structure of cell membranes // Science.-1972.-175, N 4023.-P. 720-731.

2. Somerharju P., Virtanen J. A.,Cheng K. H. Lateral organisation of membrane lipids. The superlattice view // Biochim. Biophys. Acta.-1999.-1440, N 1.-P. 32-48.

3. Vereb G., Szollosi J., Matko J., Nagy P., Farkas T., Vigh L., Matyus L., Waldmann T. A., Damjanovich $S$. Dynamic, yet struc- 
tured: The cell membrane three decades after the Singer-Nicolson model // Proc. Natl Acad. Sci. USA.-2003.-100, N 14.P. 8053-8058.

4. Hancock J. F. Lipid rafts: contentious only from simplistic standpoints // Nat. Rev. Mol. Cell Biol.-2006.-7, N 6.-P. 456-462.

5. Shaikh S. R., Edidin M. A. Membranes are not just rafts // Chem. Phys. Lipids.-2006.-144, N 1.-P. 1-3.

6. Kusumi A., Shirai Y. M., Koyama-Honda I., Suzuki K. G., Fujiwara T. K. Hierarchical organization of the plasma membrane: investigations by single-molecule tracking vs. fluorescence correlation spectroscopy // FEBS Lett.-2010.-584, N 9.-P. 1814 1823 .

7. Nichols B. Cell biology: without a raft // Nature.-2005.-436, N 7051.-P. 638-639.

8. Munro S. Lipid rafts: elusive or illusive? // Cell.-2003.-115, N 4.P. 377-388.

9. Quinn P. J. A lipid matrix model of membrane raft structure // Prog. Lipid Res.-2010.-49, N 4.-P. 390-406.

10. Frye L. D., Edidin M. The rapid intermixing of cell surface antigens after formation of mouse-human heterokaryons // J. Cell Sci.-1970.-7, N 2.-P. 319-335.

11. Stefanova I., Horejsi V., Ansotegui I. J., Knapp W., Stockinger $H$. GPI-anchored cell-surface molecules complexed to protein tyrosine kinases // Science.-1991.-254, N 5034.-P. 1016-1019.

12. Brown $D$. The tyrosine kinase connection: how GPI-anchored proteins activate T cells // Curr. Opin. Immunol.-1993.-5, N 3.P. 349-354.

13. Karnovsky M. J., Kleinfeld A. M., Hoover R. L., Klausner R. D. The concept of lipid domains in membranes // J. Cell Biol.1982.-94, N 1.-P. 1-6.

14. London $E$. How principles of domain formation in model membranes may explain ambiguities concerning lipid raft formation in cells // Biochim. Biophys. Acta.-2005.-1746, N 3.P. 203-220.

15. Lichtenberg D., Goni F. M., Heerklotz H. Detergent-resistant membranes should not be identified with membrane rafts // Trends Biochem. Sci.-2005.-30, N 8.-P. 430-436.

16. Morris R. J., Jen A., Warley A. Isolation of nano-meso scale detergent resistant membrane that has properties expected of lipid «rafts» // J. Neurochem.-2011.-116, N 5.-P. 671-677.

17. Anderson R. G., Jacobson K. A role for lipid shells in targeting proteins to caveolae, rafts, and other lipid domains // Science.2002.-296, N 5574.-P. 1821-1825.

18. Brown D. A. Analysis of raft affinity of membrane proteins by detergent-insolubility // Methods Mol. Biol.-2007.-398.-P. 9-20.

19. Zidovetzki R., Levitan I. Use of cyclodextrins to manipulate plasma membrane cholesterol content: evidence, misconceptions and control strategies // Biochim. Biophys. Acta.-2007.-1768, N 6.-P. 1311-1324.

20. Shvartsman D. E., Gutman O., Tietz A., Henis Y. I. Cyclodextrins but not compactin inhibit the lateral diffusion of membrane proteins independent of cholesterol // Traffic.-2006.-7, N 7.P. 917-926.

21. Chapkin R. S., Wang N., Fan Y. Y., Lupton J. R., Prior I. A. Docosahexaenoic acid alters the size and distribution of cell surface microdomains // Biochim. Biophys. Acta.-2008.-1778, N 2.P. 466-471.

22. Marks D. L., Bittman R., Pagano R. E. Use of Bodipy-labeled sphingolipid and cholesterol analogs to examine membrane microdomains in cells // Histochem. Cell Biol.-2008.-130, N 5.P. 819-832.
23. Juhasz J., Davis J. H., Sharom F. J. Fluorescent probe partitioning in giant unilamellar vesicles of «lipid raft» mixtures // Biochem. J.-2010.-430, N 3.-P. 415-423.

24. Gimpl G., Gehrig-Burger K. Probes for studying cholesterol binding and cell biology // Steroids.-2011.-76, N 3.-P. 216-231.

25. Klymchenko A. S., Stoeckel H., Takeda K., Mely Y. Fluorescent probe based on intramolecular proton transfer for fast ratiometric measurement of cellular transmembrane potential // J. Phys. Chem. B.-2006.-110, N 27.-P. 13624-13632.

26. Kiss E., Nagy P., Balogh A., Szollosi J., Matko J. Cytometry of raft and caveola membrane microdomains: from flow and imaging techniques to high throughput screening assays // Cytometry A.-2008.-73, N 7.-P. 599-614.

27. Garcia-Saez A. J., Schwille P. Surface analysis of membrane dynamics // Biochim. Biophys. Acta.-2010.-1798, N 4.-P. 766-776.

28. Eggeling C., Ringemann C., Medda R., Schwarzmann G., Sandhoff K., Polyakova S., Belov V. N., Hein B., von Middendorff C., Schonle A., Hell S. W. Direct observation of the nanoscale dynamics of membrane lipids in a living cell // Nature.-2009.-457, N 7233.-P. 1159-1162.

29. Wenger J., Conchonaud F., Dintinger J., Wawrezinieck L., Ebbesen T. W., Rigneault H., Marguet D., Lenne P. F. Diffusion analysis within single nanometric apertures reveals the ultrafine cell membrane organization // Biophys. J.-2007.-92, N 3.-P. 913-919.

30. van Zanten T. S., Cambi A., Garcia-Parajo M. F. A nanometer scale optical view on the compartmentalization of cell membranes // Biochim. Biophys. Acta.-2010.-1798, N 4.-P. 777-787.

31. Day C. A., Kenworthy A. K. Tracking microdomain dynamics in cell membranes // Biochim. Biophys. Acta.-2009.-1788, N 1.P. 245-253.

32. Ritchie K., Shan X. Y., Kondo J., Iwasawa K., Fujiwara T., Kusumi $A$. Detection of non-Brownian diffusion in the cell membrane in single molecule tracking // Biophys. J.-2005.-88, N 3.P. 2266-2277.

33. He H. T., Marguet D. Detecting nanodomains in living cell membrane by fluorescence correlation spectroscopy // Annu. Rev. Phys. Chem.-2011.-62.-P. 417-436.

34. Wawrezinieck L., Rigneault H., Marguet D., Lenne P. F. Fluorescence correlation spectroscopy diffusion laws to probe the submicron cell membrane organization // Biophys. J.-2005.-89, N 6.-P. 4029-4042.

35. Loura L. M., de Almeida R. F., Silva L. C., Prieto M. FRET analysis of domain formation and properties in complex membrane systems // Biochim. Biophys. Acta.-2009.-1788, N 1.-P. 209-224.

36. Rao M., Mayor S. Use of Forster's resonance energy transfer microscopy to study lipid rafts // Biochim. Biophys. Acta.2005.-1746, N 3.-P. 221-233.

37. Levitt J. A., Matthews D. R., Ameer-Beg S. M., Suhling K. Fluorescence lifetime and polarization-resolved imaging in cell biology // Curr. Opin. Biotechnol.-2009.-20, N 1.-P. 28-36.

38. de Almeida R. F., Loura L. M., Prieto M. Membrane lipid domains and rafts: current applications of fluorescence lifetime spectroscopy and imaging // Chem. Phys. Lipids.-2009.-157, N 2.-P. 61-77.

39. Gavutis M., Lata S., Piehler J. Probing 2-dimensional proteinprotein interactions on model membranes // Nat. Protoc.-2006.1, N 4.-P. 2091-2103.

40. Bagatolli L. A., Ipsen J. H., Simonsen A. C., Mouritsen O. G. An outlook on organization of lipids in membranes: searching for a realistic connection with the organization of biological membranes // Prog. Lipid Res.-2010.-49, N 4.-P. 378-389.

41. Almeida P. F., Pokorny A., Hinderliter A. Thermodynamics of membrane domains // Biochim. Biophys. Acta.-2005.-1720, N 1-2.-P. 1-13. 
42. Turner M. S., Sens $P$., Socci N. D. Nonequilibrium raftlike membrane domains under continuous recycling // Phys. Rev. Lett.2005.-95, N 16.-168301.

43. Perlmutter J. D., Sachs J. N. Interleaflet interaction and asymmetry in phase separated lipid bilayers: molecular dynamics simulations // J. Am. Chem. Soc.-2011.-133, N 17.-P. 6563 6577.

44. Silva L. C., Futerman A. H., Prieto M. Lipid raft composition modulates sphingomyelinase activity and ceramide-induced membrane physical alterations // Biophys. J.-2009.-96, N 8.P. 3210-3222.

45. Nicolini C., Baranski J., Schlummer S., Palomo J., Lumbierres-Burgues M., Kahms M., Kuhlmann J., Sanchez S., Gratton E., Waldmann H., Winter R. Visualizing association of N-ras in lipid microdomains: influence of domain structure and interfacial adsorption // J. Am. Chem. Soc.-2006.-128, N 1.-P. 192-201.

46. Marsh D. Protein modulation of lipids, and vice-versa, in membranes // Biochim. Biophys. Acta.-2008.-1778, N 7-8.-P. 15451575 .

47. Bacia K., Schuette C. G., Kahya N., Jahn R., Schwille P. SNAREs prefer liquid-disordered over «raft» (liquid-ordered) domains when reconstituted into giant unilamellar vesicles // J. Biol. Chem.2004.-279, N 36.-P. 37951-37955.

48. Lingwood D., Ries J., Schwille P., Simons K. Plasma membranes are poised for activation of raft phase coalescence at physiological temperature // Proc. Natl Acad. Sci. USA.-2008.-105, N 29.-P. 10005-10010.

49. Baumgart T., Hammond A. T., Sengupta P., Hess S. T., Holowka D. A., Baird B. A., Webb W. W. Large-scale fluid/fluid phase separation of proteins and lipids in giant plasma membrane vesicles // Proc. Natl Acad. Sci. USA.-2007.-104, N 9.-P. 31653170 .

50. Veatch S. L., Cicuta P., Sengupta P., Honerkamp-Smith A., Holowka D., Baird B. Critical fluctuations in plasma membrane vesicles // ACS Chem. Biol.-2008.-3, N 5.-P. 287-293.

51. Fantini J., Barrantes F. J. Sphingolipid/cholesterol regulation of neurotransmitter receptor conformation and function // Biochim. Biophys. Acta.-2009.-1788, N 11.-P. 2345-2361.

52. Loor F. Plasma membrane and cell cortex interactions in lymphocyte functions // Adv. Immunol.-1980.-30.-P. 1-120.

53. Spiegel S., Kassis S., Wilchek M., Fishman P. H. Direct visualization of redistribution and capping of fluorescent gangliosides on lymphocytes // J. Cell Biol.-1984.-99, N 5.-P. 1575-1581.

54. Delaunay J. L., Breton M., Trugnan G., Maurice M. Differential solubilization of inner plasma membrane leaflet components by Lubrol WX and Triton X-100 // Biochim. Biophys. Acta.-2008.1778, N 1.-P. 105-112.

55. Boon J. M., Smith B. D. Chemical control of phospholipid distribution across bilayer membranes // Med. Res. Rev.-2002.-22, N 3.P. 251-281.

56. Seigneuret M., Devaux P. F. ATP-dependent asymmetric distribution of spin-labeled phospholipids in the erythrocyte membrane: relation to shape changes // Proc. Natl Acad. Sci. USA.-1984.81, N 12.-P. 3751-3755.

57. McIntyre J. C., Sleight R. G. Fluorescence assay for phospholipid membrane asymmetry // Biochemistry.-1991.-30, N 51.P. 11819-11827.

58. Ramirez D. M., Ogilvie W. W., Johnston L. J. NBD-cholesterol probes to track cholesterol distribution in model membranes // Biochim. Biophys. Acta.-2010.-1798, N 3.-P. 558-568.

59. Best M. D., Rowland M. M., Bostic H. E. Exploiting bioorthogonal chemistry to elucidate protein-lipid binding interactions and other biological roles of phospholipids // Acc. Chem. Res.2011.-44, N 9.-P. 686-698.

60. van Engeland M., Nieland L. J., Ramaekers F. C., Schutte B., Reutelingsperger C. P. Annexin V-affinity assay: a review on an apoptosis detection system based on phosphatidylserine exposure // Cytometry.-1998.-31, N 1.-P. 1-9.

61. Ohno-Iwashita Y., Shimada Y., Hayashi M., Iwamoto M., Iwashita $S$., Inomata $M$. Cholesterol-binding toxins and anti-cholesterol antibodies as structural probes for cholesterol localization // Subcell. Biochem.-2010.-51.-P. 597-621.

62. Chap H. J., Zwaal R. F., van Deenen L. L. Action of highly purified phospholipases on blood platelets. Evidence for an asymmetric distribution of phospholipids in the surface membrane // Biochim. Biophys. Acta.-1977.-467, N 2.-P. 146-164.

63. Zachowski A. Phospholipids in animal eukaryotic membranes: transverse asymmetry and movement // Biochem. J.-1993.-294, Pt 1.-P. 1-14.

64. Kiessling $V$., Wan C., Tamm L. K. Domain coupling in asymmetric lipid bilayers // Biochim. Biophys. Acta.-2009.-1788, N 1.P. 64-71.

65. $\operatorname{Rog}$ T., Pasenkiewicz-Gierula M., Vattulainen I., Karttunen M. Ordering effects of cholesterol and its analogues // Biochim. Biophys. Acta.-2009.-1788, N 1.-P. 97-121.

66. Wang T. Y., Silvius J. R. Cholesterol does not induce segregation of liquid-ordered domains in bilayers modeling the inner leaflet of the plasma membrane // Biophys. J.-2001.-81, N 5.-P. 27622773.

67. Martinez-Seara H., Rog T., Pasenkiewicz-Gierula M., Vattulainen I., Karttunen M., Reigada R. Interplay of unsaturated phospholipids and cholesterol in membranes: effect of the doublebond position // Biophys. J.-2008.-95, N 7.-P. 3295-3305.

68. Di Paolo G., De Camilli P. Phosphoinositides in cell regulation and membrane dynamics // Nature.-2006.-443, N 7112.P. 651-657.

69. Fadeel B., Xue D. The ins and outs of phospholipid asymmetry in the plasma membrane: roles in health and disease // Crit. Rev. Biochem. Mol. Biol.-2009.-44, N 5.-P. 264-277.

70. Mesmin B., Maxfield F. R. Intracellular sterol dynamics // Biochim. Biophys. Acta.-2009.-1791, N 7.-P. 636-645.

71. Lange Y., Steck T. L. Cholesterol homeostasis and the escape tendency (activity) of plasma membrane cholesterol // Prog. Lipid Res.-2008.-47, N 5.-P. 319-332.

72. Epand R. M. Proteins and cholesterol-rich domains // Biochim. Biophys. Acta.-2008.-1778, N 7-8.-P. 1576-1582.

73. Contreras F. X., Sanchez-Magraner L., Alonso A., Goni F. M. Transbilayer (flip-flop) lipid motion and lipid scrambling in membranes // FEBS Lett.-2010.-584, N 9.-P. 1779-1786.

74. Poulsen L. R., Lopez-Marques R. L., Palmgren M. G. Flippases: still more questions than answers // Cell. Mol. Life Sci.-2008.65, N 20.-P. 3119-3125.

75. Devaux P. F., Herrmann A., Ohlwein N., Kozlov M. M. How lipid flippases can modulate membrane structure // Biochim. Biophys. Acta.-2008.-1778, N 7-8.-P. 1591-1600.

76. Demchenko A. P., Yesylevskyy S. O. Nanoscopic description of biomembrane electrostatics: results of molecular dynamics simulations and fluorescence probing // Chem. Phys. Lipids.-2009.160, N 2.-P. 63-84.

77. Pohl A., Lopez-Montero I., Rouviere F., Giusti F., Devaux P. F. Rapid transmembrane diffusion of ceramide and dihydroceramide spin-labelled analogues in the liquid ordered phase // Mol. Membr. Biol.-2009.-26, N 3.-P. 194-204.

78. Bennett W. F., MacCallum J. L., Hinner M. J., Marrink S. J., Tieleman D. P. Molecular view of cholesterol flip-flop and chemi- 
cal potential in different membrane environments // J. Am. Chem. Soc.-2009.-131, N 35.-P. 12714-12720.

79. Sanyal S., Menon A. K. Flipping lipids: why an' what's the reason for? // ACS Chem. Biol.-2009.-4, N 11.-P. 895-909.

80. Collins $M$. D. Interleaflet coupling mechanisms in bilayers of lipids and cholesterol // Biophys. J.-2008.-94, N 5.-P. L32-34.

81. Collins M. D., Keller S. L. Tuning lipid mixtures to induce or suppress domain formation across leaflets of unsupported asymmetric bilayers // Proc. Natl Acad. Sci. USA.-2008.-105, N 1.P. 124-128.

82. Putzel G. G., Schick M. Phase behavior of a model bilayer membrane with coupled leaves // Biophys. J.-2008.-94, N 3.P. 869-877.

83. Horner A., Antonenko Y. N., Pohl P. Coupled diffusion of peripherally bound peptides along the outer and inner membrane leaflets // Biophys. J.-2009.-96, N 7.-P. 2689-2695.

84. Gri G., Molon B., Manes S., Pozzan T., Viola A. The inner side of T cell lipid rafts // Immunol. Lett.-2004.-94, N 3.-P. 247-252.

85. Wu M., Holowka D., Craighead H. G., Baird B. Visualization of plasma membrane compartmentalization with patterned lipid bilayers // Proc. Natl Acad. Sci USA.-2004.-101, N 38.-P. 13798 13803.

86. Westerlund B., Slotte J. P. How the molecular features of glycosphingolipids affect domain formation in fluid membranes // Biochim. Biophys. Acta.-2009.-1788, N 1.-P. 194-201.

87. Prinetti A., Loberto N., Chigorno V., Sonnino S. Glycosphingolipid behaviour in complex membranes // Biochim. Biophys. Acta.-2009.-1788, N 1.-P. 184-193.

88. Mishra S., Joshi P. G. Lipid raft heterogeneity: an enigma // J. Neurochem.-2007.-103, Suppl 1.-P. 135-142.

89. Valensin S., Paccani S. R., Ulivieri C., Mercati D., Pacini S., Patrussi L., Hirst T., Lupetti P., Baldari C. T. F-actin dynamics control segregation of the TCR signaling cascade to clustered lipid rafts // Eur. J. Immunol.-2002.-32, N 2.-P. 435-446.

90. Chichili G. R., Rodgers W. Cytoskeleton-membrane interactions in membrane raft structure // Cell. Mol. Life Sci.-2009.-66, N 14.-P. 2319-2328.

91. Meiri K. F. Membrane/cytoskeleton communication // Subcell. Biochem.-2004.-37.-P. 247-282.

92. Andrews N. L., Lidke K. A., Pfeiffer J. R., Burns A. R., Wilson B. S., Oliver J. M., Lidke D. S. Actin restricts FcepsilonRI diffusion and facilitates antigen-induced receptor immobilization // Nat. Cell Biol.-2008.-10, N 8.-P. 955-963.

93. Kabouridis P. S. Lipid rafts in T cell receptor signalling// Mol. Membr. Biol.-2006.-23, N 1.-P. 49-57.

94. Doherty G. J., McMahon H. T. Mediation, modulation, and consequences of membrane-cytoskeleton interactions // Annu. Rev. Biophys.-2008.-37.-P. 65-95.

95. Manno S., Takakuwa Y., Mohandas N. Identification of a functional role for lipid asymmetry in biological membranes: Phosphatidylserine-skeletal protein interactions modulate membrane stability // Proc. Natl Acad. Sci. USA.-2002.-99, N 4.-P. 19431948.

96. Demchenko A. P., Mely Y., Duportail G., Klymchenko A. S. Monitoring biophysical properties of lipid membranes by environment-sensitive fluorescent probes // Biophys. J.-2009.-96, N 9.P. 3461-3470.

97. Yeung T., Gilbert G. E., Shi J., Silvius J., Kapus A., Grinstein S. Membrane phosphatidylserine regulates surface charge and protein localization // Science.-2008.-319, N 5860.-P. 210-213.

98. Gurtovenko A. A., Vattulainen I. Effect of $\mathrm{NaCl}$ and $\mathrm{KCl}$ on phosphatidylcholine and phosphatidylethanolamine lipid memb- ranes: insight from atomic-scale simulations for understanding salt-induced effects in the plasma membrane // J. Phys. Chem. B.-2008.-112, N 7.-P. 1953-1962.

99. Gurtovenko A. A., Vattulainen I. Intrinsic potential of cell membranes: opposite effects of lipid transmembrane asymmetry and asymmetric salt ion distribution // J. Phys. Chem. B.-2009.-113, N 20.-P. 7194-7198.

100. Lee S. J., Song Y., Baker N. A. Molecular dynamics simulations of asymmetric $\mathrm{NaCl}$ and $\mathrm{KCl}$ solutions separated by phosphatidylcholine bilayers: potential drops and structural changes induced by strong $\mathrm{Na}^{+}$-lipid interactions and finite size effects // Biophys. J.-2008.-94, N 9.-P. 3565-3576.

101. Vacha R., Jurkiewicz P., Petrov M., Berkowitz M. L., Bockmann R. A., Barucha-Kraszewska J., Hof M., Jungwirth P. Mechanism of interaction of monovalent ions with phosphatidylcholine lipid membranes // J. Phys. Chem. B.-2010.-114, N 29.-P. 95049509.

102. Demchenko A. P. Introduction to fluorescence sensing.-Amsterdam: Springer, 2009.-590 p.

103. Demchenko A. P. The concept of lambda-ratiometry in fluorescence sensing and imaging // J. Fluoresc.-2010.-20, N 5.-P. 10991128.

104. Klymchenko A. S., Duportail G., Ozturk T., Pivovarenko V. G., Mely Y., Demchenko A. P. Novel two-band ratiometric fluorescence probes with different location and orientation in phospholipid membranes // Chem. Biol.-2002.-9, N 11.-P. 1199-1208.

105. Millard A. C., Jin L., Wei M. D., Wuskell J. P., Lewis A., Loew $L$. $M$. Sensitivity of second harmonic generation from styryl dyes to transmembrane potential // Biophys. J.-2004.-86, N 2.P. 1169-1176.

106. Jin L., Millard A. C., Wuskell J. P., Dong X., Wu D., Clark H. A., Loew L. M. Characterization and application of a new optical probe for membrane lipid domains // Biophys. J.-2006.-90, N 7.P. 2563-2575

107. Kim H. M., Choo H. J., Jung S. Y., Ko Y. G., Park W. H., Jeon S. J., Kim C. H., Joo T., Cho B. R. A two-photon fluorescent probe for lipid raft imaging: C-laurdan // Chembiochem.-2007.-8, N 5.P. 553-559.

108. Kim H. M., Jeong B. H., Hyon J. Y., An M. J., Seo M. S., Hong J. H., Lee K. J., Kim C. H., Joo T., Hong S. C., Cho B. R. Twophoton fluorescent turn-on probe for lipid rafts in live cell and tissue // J. Am. Chem. Soc.-2008.-130, N 13.-P. 4246-4247.

109. Shynkar V. V., Klymchenko A. S., Kunzelmann C., Duportail G., Muller C. D., Demchenko A. P., Freyssinet J. M., Mely Y. Fluorescent biomembrane probe for ratiometric detection of apoptosis // J. Am. Chem. Soc.-2007.-129, N 7.-P. 2187-2193.

110. Goldenberg N. M., Steinberg B. E. Surface charge: a key determinant of protein localization and function // Cancer Res.-2010.70, N 4.-P. 1277-1280

111. Hynes $R$. $O$. Integrins: bidirectional, allosteric signaling machines // Cell.-2002.-110, N 6.-P. 673-687.

112. Chichili G. R., Westmuckett A. D., Rodgers W. T cell signal regulation by the actin cytoskeleton // J. Biol. Chem.-2010.-285, N 19.P. 14737-14746.

113. Yokosuka T., Saito T. The immunological synapse, TCR microclusters, and T cell activation // Curr. Top. Microbiol. Immunol.2010.-340.-P. 81-107.

114. van Meer G. Cellular lipidomics // EMBO J.-2005.-24, N 18.P. 3159-3165.

Received 07.06.11 